\title{
MECHANICAL PROPERTIES OF THE HUMAN LUMBAR DURA MATER
}

\author{
EDMUNDO ZARZUR
}

\begin{abstract}
Background and objectives: This study aimed to evaluate the transverse and longitudinal distensibility of the posterior human lumbar dura mater. Results are compared with previous literature on biomechanical property studies. Possible clinical implications were also examined. Methods: Samples of human dural sac were obtained from autopsy studies in three adult male cadavers. Dural sac samples were sectioned longitudinally to measure transverse and longitudinal distensibility, thickness and circumference. Results: It was recorded that the posterior lumbar dura mater was easily distensible only in the transverse direction. The longitudinal force required to distend and rupture the posterior lumbar dura mater samples is 3.5 to 6.7 times greater than the force to produce a transversal rupture. Conclusion: Depending on the local cerebrospinal fluid pressure, the documented easier transverse distensibility of the posterior lumbar dura mater may allow greater contact of the lumbar dural sac with the wall of the lumbar verterbral canal. This fact may affect the diffusion of solutions introduced into epidural space.
\end{abstract}

KEY WORDS: dura mater, distensibility thickness, load at rupture, modulus of elasticity, strain at rupture.

\section{Propriedades mecânicas da dura máter lombar humana}

RESUMO - Este estudo procura avaliar as distensibilidades transversal e longitudinal da dura máter lombar na sua porção posterior. Os resultados são comparados com os de outras investigações publicadas sobre as propriedades biomecânicas da dura máter. Métodos: Amostras de dura máter foram obtidas de autópsias realizadas em três cadáveres de homens adultos. As amostras do saco dural foram secionadas longitudinalmente para permitir as seguintes medições: distensibilidade transversal e longitudinal, espessura da dura máter e circunferência do saco dural. Resultados: Foi constatado que a dura máter lombar na sua porção posterior é facilmente distensivel. Para distender e romper longitudinalmente esta mesma dura máter, necessita-se de 3,5 a 6,7 vezes mais força do que a necessária para a sua distensão e rompimento na direção transversal. Conclusão: Dependendo da pressão do líquido cefalorraqueano, a fácil distensibilidade transversal da dura máter possibilita maior contato do saco dural lombar com a parede do canal vertebral. Este fato pode influir na difusĩo das soluções introduzidas no espaço peridural.

PALAVRAS-CHAVE: dura máter, distensibilidade, espessura, força para rompimento, módulo de elasticidade.

Little attention has been paid to the elasticity and thickness of the human dura mater. Its elastic property is due to elastic fibers found intermixed with collagen fibers ${ }^{4}$. Collagen fibers are the dominant component found in the human lumbar dura mater ${ }^{9}$. The elastic and collagen fibers are not arranged in an exclusive cephalocaudal direction. It has been shown that both types of fibers are

* MD. This study has been carried out at the Department of Pathology and in the Biomechanics Laboratory of the Orthopedics and Traumatology Institute (LIM 4) of the University of São Paulo Medical School, São Paulo City, Brazil and it was approved by the Committee on Human Ethics and Research. This investigation has been presented in part in the First Pan American Symposium on Regional Anesthesia. São Paulo, Brazil in March 4-6, 1993. Aceite:3-maio-1996.

Dr. Edmundo Zarzur - Rua Ziembinski 314 - 05086-020 Sāo Paulo SP - Brasil. 
arranged in multiple directions. This present study was originally conceived as the result of unpublished observations recorded by the author during anatomic studies of the human lumbar ligamenta flava in twelve fresh cadavers. In those studies, it was visually recorded that the lumbar dura mater was easily distensible by hand only in the transverse direction.

The aim of this study was to perform detailed investigations on the distensiblility of the posterior human lumbar dura mater obtained from fresh cadavers and preserved in formalin for 72 hours before testing and the results compared with previous literature on biomechanical properties studies $^{10.17}$. Possible clinical implications were also examined.

\section{MATERIAL AND METHODS}

Samples of dural sac were obtained from autopsy studies in three adult fresh male cadavers. Cadaver number one was 38 years old; height $=1.60 \mathrm{~m}$; weight $=60 \mathrm{Kg}$; gender: male. Cadaver number two was 58 years old; height $=1.80 \mathrm{~m}$; weight $=70 \mathrm{Kg}$; gender: male. Cadaver number three was 73 years old; height $=1.60 \mathrm{~m}$; weight=78 Kg; gender: male. Dura mater samples were preserved in formalin in the study herein. In order to minimize changes in the dura mater protein structure produced by formalin, testing was performed 72 hours after the samples were obtained from autopsies.

To calculate dural sac diameter, the anterior dura mater was sectioned in the longitudinal direction and the circumference was measured ( $D=C / \pi D$ - diameter $C$ - circumference). Fragments of the posterior lumbar dura mater were cut into two $4 \mathrm{~cm}^{2}(2 \mathrm{~cm}$ by $2 \mathrm{~cm})$ pieces. Dura mater dimensions were measured with a micrometer and caliper. Each $4 \mathrm{~cm}^{2}$ piece obtained from the same subject was stretched either in the longitudinal or transverse direction. Sample stretching was performed at a $20-\mathrm{mm}$-per-minute rate to the point of rupture in a conventional test.

Transverse and longitudinal distensibility (strain at rupture) and the tensile forces necessary for tissue rupture (load at rupture) are shown in the diagrams. Samples were tested with a Universal Test Machine, "Kratos" K 5002 (São Paulo, Brazil).

In an attempt to describe some of the posterior lumbar dura mater mechanical properties, the following parameters were calculated:

1. Strain at rupture: This parameter is expressed in percentage. It consists of change in length divided by the original length of the sample.

2. Load at rupture: It is expressed in Newtons and represents the force required to cause distention and tissue rupture.

3. Modulus of elasticity:

$E=\frac{L \Delta I\left(N / m^{2}\right)}{S_{0} I}$

where: $\mathrm{L}=$ load $(\mathrm{N}) ; \mathrm{S}_{0}=$ sectional area in $\mathrm{m}^{22} \mathrm{E}=$ modulus of elasticity; $\mathrm{I}=$ initial length in meter; $\Delta \mathrm{I}=$ elongation (m).

Descriptive statistical analyses of all ordinal parameters were performed. Longitudinal and transversal groups were compared by the non-parametric Mann-Whitney U test. Significant level of $5 \%(\alpha=0.05)$ was adopted. Statistically significant results were indicated with an asterix $\left({ }^{*}\right)$.

\section{RESULTS}

The main consistent findings of this study were that the longitudinal force required for tissue distention and tissue rupture of the posterior human lumbar dura mater are 3.5 to 6.7 greater than the transverse force to produce a rupture for corresponding individual adult samples. Additionally, the strain at rupture in the transverse direction ranged from $32.0 \%$ to $53.1 \%$ of the initial length. The longitudinal and transversal strain at rupture was smaller in the 73-year-old male cadaver (Table 1).

Modulus of elasticity at rupture are shown in Table 2.

Table 3 shows the lumbar dural sac diameter and posterior lumbar dura mater thickness.

The transverse and longitudinal distensibility and the tensile forces required for tissue distention and tissue rupture are graphically represented in the Figure. The plots depict the easier transverse distention of the $20 \mathrm{~mm}$ by $20 \mathrm{~mm}$ samples. 
Table 1 . Strain at rupture = change in length of the posterior dura mater in percent and load at rupture in Newtons.

\begin{tabular}{|c|c|c|c|c|c|}
\hline \multirow[b]{2}{*}{ Specimen } & \multirow[b]{2}{*}{$\begin{array}{l}\text { Age } \\
(y r)\end{array}$} & \multicolumn{2}{|c|}{ Transverse } & \multicolumn{2}{|c|}{ Longitudinal } \\
\hline & & $\begin{array}{c}\text { Strain } \\
(\%)\end{array}$ & $\begin{array}{l}\text { Load } \\
(\mathrm{N})\end{array}$ & $\begin{array}{c}\text { Strain } \\
(\%)\end{array}$ & $\begin{array}{c}\text { Load } \\
\text { (N) }\end{array}$ \\
\hline 1 & 36 & 53.1 & 15.2 & 43.7 & 54.2 \\
\hline 2 & 58 & 50.4 & 9.8 & 49.7 & 51.8 \\
\hline 3 & 73 & 32.0 & 6.4 & 25.8 & 43.1 \\
\hline $\mathbf{M}$ & 55.67 & 45.16 & 10.46 & 39.73 & 49.70 \\
\hline SD & 18.61 & 11.48 & 4.44 & 12.43 & 5.84 \\
\hline SEM & 10.74 & 6.63 & 2.56 & 7.18 & 3.37 \\
\hline
\end{tabular}

Mann Whitney

U Test
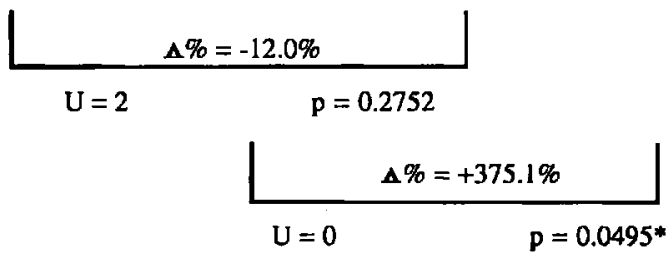

Table 2. Modulus of elasticity in $\mathrm{N} / \mathrm{m}^{2}$.

\begin{tabular}{|c|c|c|c|}
\hline Specimen & Age (yr) & Transverse & Longitudinal \\
\hline 1 & 36 & 26.9 & 171.5 \\
\hline 2 & 258 & 11.2 & 85.2 \\
\hline 3 & 73 & 18.4 & 104.2 \\
\hline $\mathbf{M}$ & 55.7 & 18.83 & 120.30 \\
\hline SD & 18.6 & 7.86 & 45.35 \\
\hline SEM & 10.7 & 4.54 & 26.18 \\
\hline Mann Whitney & & \multicolumn{2}{|c|}{$\Delta \%=+538.9 \%$} \\
\hline \multicolumn{2}{|l|}{ U Test } & $\mathrm{U}=0$ & $p=0.0495^{*}$ \\
\hline Specimen & Age (yr) & Diameter (mm) & Thickness (mm) \\
\hline 1 & 36 & 14.00 & 0.10 \\
\hline 2 & 58 & 13.37 & 0.20 \\
\hline 3 & 73 & 14.96 & 0.25 \\
\hline $\mathbf{M}$ & 55.7 & 14.11 & 0.18 \\
\hline SD & 18.6 & 0.80 & 0.08 \\
\hline SEM & 10.7 & 0.46 & 0.04 \\
\hline
\end{tabular}




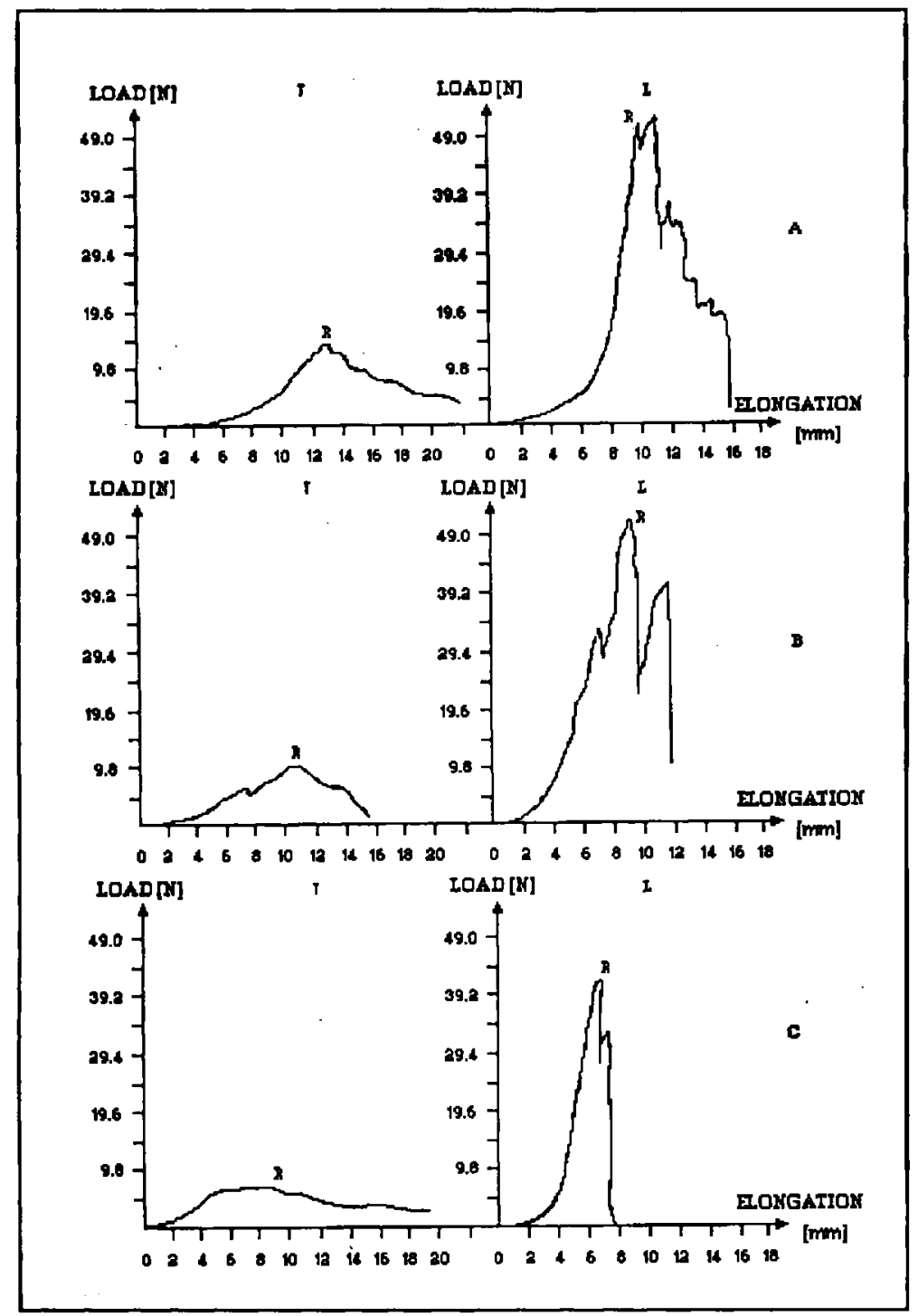

Figure. Typical recordings of peak tensile forces related to the distensibilities and tissue ruptures of the three $20 \mathrm{~mm}$ by $20 \mathrm{~mm}$ each samples of lumbar dura mater. (A) sample 1 . (B) sample 2. (C) sample 3. (T) transverse distensibility. (L) longitudinal distenbility. (R) rupture.

\section{DISCUSSION}

Unpublished observations made by the author recorded during anatomic studies in 12 fresh cadavers demonstrated that the lumbar dura mater can be easily stretched manually only in the transverse direction. These findings were also observed after the fresh lumbar dura mater was preserved in formalin. The present study showed that the transverse force required for tissue distention and rupture of the posterior lumbar dura mater was 3.5 to 6.7 times smaller than the longitudinal force for corresponding individual samples. 
This study shows that the results obtained with formalin-preserved dura mater are comparable with the data brought about with saline-preserved dura mater obtained from autopsy studies in five adult subjects (age range 32 to 62 years) ${ }^{10}$. Additionally, the data reported herein are similar to the data from the author's previous investigation where formalin-preserved dura mater was employed".

What is the importance of the easier transverse distensibility of the lumbar dura mater as shown by this study? What is the relationship of the cylindrical dural sac with the lumbar vertebral canal wall?

In order to understand the questions above, it would be convenient to have a better understanding of vertebral canal anatomy. The shape of the human lumbar vertebral canal when seen at the level of the pedicles tends to be oval or circular ${ }^{11.18}$. At this level, the epidural space is empty because the dural sac is in direct contact with the canal wall. When the vertebral canal is seen at the level of the lower border of the ligamenta flava, the shape of the vertebral canal is clearly triangular ${ }^{16.18}$. At this level, the epidural space has three compartments in each lumbar segment, one posterior and two lateral compartments ${ }^{6}$. The posterior compartment is triangular and it contains fat, whereas the lateral compartments contain nerve roots, fat, blood and lymphatic vessels. The posterior and lateral compartments are circumferentially and longitudinally separated by areas at the level of the pedicles where the cylindrical dural sac is in direct contact with the wall of the lumbar vertebral canal'. Changes in the body position have considerable effects on the cerebrospinal fluid (CSF) pressure which is transmitted to the epidural space. On a lateral decubitus, the CSF pressure is approximately the same at all levels. Mean value CSF pressure measures $16.7 \pm 4.1 \mathrm{~cm}$ of water in the lumbar segment and $11.9 \pm 4.0 \mathrm{~cm}$ of water at the level of the cisterna magna ${ }^{14}$. In the right lateral decubitus position with an incomplete flexion of the vertebral column, the CSF pressure measures $13 \pm 3 \mathrm{~cm}$ of water at the L2-L3 level and it increases to $21 \pm 5 \mathrm{~cm}$ of water with a full-flexed position ${ }^{15}$. The lumbar CSF pressure rises to $40 \mathrm{~cm}$ of water in a sitting position whereas cisternal CSF pressure falls to -4 to $-8 \mathrm{~cm}$ of water ${ }^{3}$.

Thus, it is possible to change the lumbar and thoracic CSF pressures by changing the patient's vertebral column position. The cylindrical dural sac exerts different degrees of pressure on the wall of the lumbar vertebral canal depending on the local CSF pressure. In a situation in which the CSF pressure is high, there might be a greater transverse distention of the dural sac.

This causes greater physical contact between the dura mater and the wall of the circular part of the lumbar vertebral canal, and therefore, an increase in the epidural space pressure. The lumbar epidural pressure is positive and it bears a clear relationship with the local CSF pressure ${ }^{12,13}$. It has been demonstrated that the epidural space pressure is in balance with the prevailing CSF pressure ${ }^{12.13}$. This CSF pressure maintains the dura mater opposed to the vertebral canal wall. Although this fact may affect the diffusion of solutions introduced into the posterior epidural compartment, solutions injected into the epidural space can pass from one compartment to another because the dura mater is not attached to canal wall.

The CSF pressure is lower in the upright position at the cervical and thoracic level than at the lumbar level in the sitting position. There is less resistance to spread cephalic than caudal and hence solutions introduced into the lumbar epidural space tend to flow upwards rather than downwards ${ }^{12,13}$.Supporting this concept, it can be mentioned the research on the spread of solutions injected into the lumbar epidural space. These studies suggest that the sitting position allowed no actual advantage to patients regarding the blockade of sacral nerves. On the contrary, the sitting position seemed to limit the caudal spread of the solution injected in the lumbar epidural space ${ }^{2.7}$. Nuclear magnetic resonance imaging studies of epidural blood patches showed that the spread of the clot with the patient in the sitting position was mainly upwards from the injection site ${ }^{13}$.

The transverse and longitudinal distensibility measures of the posterior lumbar dura mater were lower in the 73-year-old patient than in the other samples. Presumably, in the case of this 73- 
year-old subject, as happens with the ligamenta flava of elderly subjects, the dura mater elastic fibers are substituted by collagen fibers. The collagen fibers act as an extension-limiting component of the tissue $^{89}$. This extension-limiting phenomenon causes the hole edges created by the needle bevel to gape less in the event of a higher CSF pressure, causing less CSF leakage. This hypothesis may account for the fact that some patients, mainly elderly subjects, who have a physiologically lower CSF pressure, do not develop a headache despite the use of a large-gauge needle.

This study shows that the results obtained with formalin-conserved dura mater for 72 hours are comparable with the data obtained from studies using dura mater conserved in saline solution ${ }^{10}$. The results are proportional in all specimens: the posterior lumbar dura mater is easily distensible in the transverse direction and the longitudinal force required for tissue distention and tissue rupture of the posterior lumbar dura mater were many times greater than the transverse force for corresponding individual specimens (Figure),

Further studies are necessary to clarify the role of dura mater dynamics regarding its distensibility in young and elderly patients to give a better understanding of the mechanics controlling the spread of solutions within the epidural space.

Acknowledgements - The author is thankful to Tomaz Pugas Leivas for his technical assistance in the mechanical assays and statistical analysis. The author is also thankful to Armando Fortuna, Professor and Chairman of the Department of Anesthesiology of the Hospital Beneficiência Portuguesa in Santos, São Paulo State and Dr. Flávio Alóe for his helpful assistance and suggestions in preparing this manuscript.

\section{REFERENCES}

1. Beard SC, Jackson A, Griffths AG, Horsman EL. Magnetic resonance imaging of extradural blood patches: appeurances from 30 minutes to 18 hours. Br J Anuesth 1993;71:182-188.

2. Burn JM, Guyer PB, Langdon L. The spread of solutions injected into epidural space: a study using epidurograms in patients with the lumbosciatic syndrome. Br J Anaesth 1973;45:338-344.

3. Evans FT, Gray TC. General anaesthesia. London: Hazzell Watson \& Viney, 1965:273.

4. Fink BR, Walker $S$. Orientution of fibers in human dorsal lumbar dura mater in relation to lumbar puncture. Anesth Analg 1989;69:768-772.

5. Griffiths AG, Beards SC, Jackson A, Horsman EL. Visualization of extradural blood patch for post lumbar headache by magnetic resonance imaging. Br J Anaesth 1993;70:223-225.

6. Hogan QH. Lumbur epidural anatomy: a new look by cryomicrotome section. Anesthesiology 1991;75:767-775.

7. Merry AF, Cross JA, Mayadeo SV, Wild CJ. Posture and the spread of extradural analgesia in labour. Br J Anesth 1983;85:303-306.

8. Nackemson AL. Some mechanical properties of the third human lumbar interlaminar ligament (ligamentum flavum). J Biomechanics 1968;1:211-221.

9. Nakagawa H, Mikawa Y, Watanabe R. Elastin in the human posterior longitudinal ligament and spinal dura: a histologic and biomechanical study. Spine 1994:1:2164-2169

10. Patin DJ, Eckstein EC, Harum K, Pallares VS. Anatomic and biochemical properties of human lumbar dura mater. Anesth Analg 1993;76:535-540.

11. Postacchini F, Pezzeri G, Montanaro A, Natali G. Computerized tomography in lumbar stenosis: a preliminary report. J Bone Joint Surg 1980;62-B:78-82.

12. Shah JL. Influence of cerebrospinal fluid on epidural pressure. Anaesthesia 1981;36:627-631.

13. Shah JL. Positive lumbar extradural space pressure. Brit J An:esth 1994;73:309-314.

14. Spina-França A. Variaçőes fisiológicas da pressão de líquido cefalorraqueano na cisterna magna. Arq de Neuropsiquiatr 1963;21:19-24.

15. Watanabe S, Yamaguchi Y, Ishizawa $Y$. Level of spinal anesthesia can be predicted by cerebrospinal fluid pressure difference between full-flexed and non-full-flexed lateral position. Anesth Analg 1991;73: 391-393.

16. Zarzur E. Anatomic studies of the human ligamentum flavum. Anesth Analg 1984;63:499-502

17. Zarzur E. Some mechanical properties of the human spinal dura mater. Reg Anesth 1993;18(Suppl): IS26.

18. Zarzur E. The shape of the human lumbar vertebral canal. Reg Anesth 1993;18:(Suppl):1S27. 